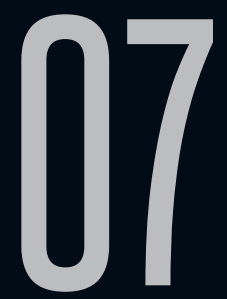

\title{
O GÓTICO E A FIGURA DO DUPLO EM “USS CALLISTER"
}

Pedro Sasse (UFF)

Victoria Barros Moura (UFF)

Recebidoem 15 jan 2020. Pedro Sasse é Doutor em Estudos de Literatura Aprovado em 11 mai 2020. pela Universidade Federal Fluminense na área de Literatura, História e Cultura, coordenador do Grupo de Estudos "Escritos Suspeitos" (UFF) e membro dos grupos de pesquisas "Estudos do Gótico" (CNPq) e "Interferências: literatura e ciência". Possui experiência na área de Teoria Literária e Literatura Comparada, com ênfase em: literatura criminal, literatura distópica, gótico, violência urbana, terror.

Victoria Barros Moura é Mestranda em Estudos da Literatura - Literaturas Estrangeiras Modernas pela UFF, com ênfase em Literaturas de Língua Inglesa. Pesquisa a figura do duplo na literatura no final do século XIX e início do XX, e também em obras contemporâneas. Suas áreas de interesse são literatura gótica, literatura fantástica e distopia.

Resumo: Este artigo tem como objetivo investigar a forma como a figura do duplo é representada no cenário da ficção científica. Para tal análise, o episódio "USS Callister" (2017), da série de televisão britânica Black Mirror, será utilizado. Por ser um produto de ficção científica, a criação de um duplo é possível através da reprodução do eu, através 
de procedimentos tecnológicos. É interesse deste artigo analisar as consequências desta reprodução: a objetificação da cópia para benefício próprio, a busca pelo poder sobre o outro e o fato de que o Homem usa a duplicação como instrumento de punição. No que diz respeito à literatura, Julian Wolfreys (2002), utilizando o conceito de unheimlich de Freud (2010), analisa a ameaça que o duplo é capaz de despertar no eu original. Ele observa que, ao mesmo tempo em que o elemento inquietante vem de um lugar familiar, ele fora reprimido; o que assombra o indivíduo é a volta do que foi renegado. Já, em "USS Callister", por sua vez, o duplo não é a única figura que assombra; o Homem assume essa posição quando decide criar cópias humanas, com o propósito de explorá-las para satisfação pessoal. Nessa inversão de papéis, em que a figura monstruosa consiste no ser humano e a vítima é representada pelo duplo, portanto, este artigo não só se propõe a investigar como a representação do duplo é possível dentro da ficção científica, mas também como ela é capaz de revelar um lado sombrio e cruel no Homem, uma vez que ele se mostra disposto a objetificar uma parte do outro para se beneficiar, de alguma maneira.

Palavras-chave: Duplo; Controle; Monstruosa; Reprodução.

Abstract: This article aims to investigate the way the figure of the double is represented in the sciencefiction scenario. For such an analysis, the episode "USS Callister" (2017) will be used, from the British television series Black Mirror. As it is a science-fiction work, the creation of the double is possible due to the reproduction of one's Self, through technological procedures. This article is interested in analyzing the consequences of this reproduction: the objectification of the Other, for the original's own benefit, the search for power over the Other and the fact that Man uses the duplication as an instrument of punishment. 
Regarding literary works, Julian Wolfreys (2002), using the concept of the unheimlich by Freud (2010), studies the threat that the double is capable of awakening in the original Self. He observes that, at the same time the uncanny element comes from a familiar place, it has been repressed; what haunts the individual is the return of what has been disowned. On the other hand, in "USS Callister", the double is not the only figure which haunts; humankind assumes this position when they decide to create human copies in order to explore them for personal satisfaction. In this role reversal, in which the monstrous figure consists in the human being and the victim is represented by the double, therefore, this article not only proposes to investigate how the representation of the double is possible inside science-fiction, but also how it is able to reveal a dark and cruel side in humankind, since they show they are eager to objectify a part of the Other for their own benefit, somehow.

Keywords: Double; Control; Monstrous; Reproduction.

É inquestionável o fato de que a figura do duplo é bem frequente na literatura; há muitas obras renomadas que abordam essa temática, como os romances $O$ Retrato de Dorian Gray (1890), de Oscar Wilde, O Homem Duplicado (2002), de José Saramago, ou contos literários, como "William Wilson" (1839), de Edgar Allan Poe e "The Jolly Corner" (1908), de Henry James. Observa-se também que o duplo é um tema atemporal. Isto é, desde a época das peças de teatro gregas, como $O$ Anfitrião, até a contemporaneidade, podemos ver obras em que essa figura aparece, mesmo que representada de diferentes formas - através de doppelgängers, imagens espelhadas, fantasmas, entre outros.

Entretanto, não é apenas na literatura que a figura do duplo é recorrente; ela também aparece em outros veículos midiáticos, 
como filmes, séries de televisão e até novelas. Por ter relação com questões envolvendo identidade e até uma possível dissociação do eu, o duplo é sempre muito atual, permeando diversas gerações. Para investigar, neste artigo, a relação do duplo dentro de um contexto contemporâneo, irei utilizar um dos episódios da série de televisão britânica, Black Mirror, "USS Callister" (2017). Primeiramente, essa série foi escolhida como objeto de estudo, uma vez que seus episódios são independentes; ou seja, a narrativa de "USS Callister" não depende do enredo de episódios anteriores, pois cada um conta uma história diferente.

Vale ressaltar que a série de televisão em questão teve uma ótima aceitação por parte do público. Kelly Hurley, na introdução de The Gothic Body (1996), "The abhuman", observa que, para entender a cultura de uma sociedade, é preciso estudar a cultura de massa presente na mesma (p.4-5). Hurley ainda cita Terry Eagleton quando este afirma em Marxism and Literary Criticism que um desenvolvimento significativo na literatura acontece ou até um novo modo artístico surge a partir de uma demanda coletiva, provocada pela cultura de massa (EAGLETON, 1976, p.20). Isto é, não só na literatura, mas também em produtos televisivos, é válido investigar o que os indivíduos estão consumindo como forma de entretenimento, a fim de refletir o que esse consumo diz a respeito de sua sociedade.

Antes de entrar na análise do episódio em questão, para explicar um pouco como o universo "Black Mirror" é pensado, André Cardoso, em "Precarious humanity: the dystopian double", observa que não há forma de apontar um único exemplo como detentor de autoridade nas tramas de Black Mirror, apesar de 
retratarem sociedades essencialmente autoritárias (2018, p.896). Na série, o poder é pulverizado; sendo assim, ele toma forma nas interações que acontecem dentro das relações sociais, podendo ser exercido por pessoas distintas e em ocasiões distintas (CARDOSO, 2018, p.896). O aspecto importante acerca do poder em Black Mirror é que ele acontece com a finalidade de obter o controle sobre si mesmo e sobre o outro. Cardoso ainda complementa afirmando que essa intensificação na busca por poder e controle são reflexos de uma sociedade egoísta e narcisista (2018, p.896), como é o caso de "USS Callister", que será discutido nas próximas seções.

\section{MULTIPLICAÇÃO DE DNA E ALTER-EGO}

O primeiro episódio da quarta temporada de Black Mirror, "USS Callister" conta a história de Robert Daly, o cofundador e programador de uma empresa chamada Callister Inc. Ele é o responsável pela criação de um jogo de realidade simulada através de interfaces neurais. O jogo é considerado um sucesso e é jogado por milhares de pessoas, inclusive os próprios funcionários de sua empresa fundadora.

Daly é o típico nerd que vive para o trabalho, introvertido e sem muitos amigos. Por ser introspectivo e não ter muitos relacionamentos cordiais na firma, é considerado um weirdo ${ }^{1}$ pelas pessoas que trabalham com ele, sendo até alvo de comentários com um tom de deboche, por alguns deles. O programador encontra uma forma de escapar dessa realidade solitária através do jogo que ele mesmo criou - o qual ele joga sozinho, usando o 
DNA de seus colegas de trabalho para reproduzir cópias digitais dos mesmos, a fim de que eles participem do jogo junto com ele. Neste jogo, Robert Daly é o capitão de uma nave espacial, comandando sua tripulação pelo espaço, composta pelos companheiros de trabalho de Daly.

Um dos diferenciais de Black Mirror é que, como já dito, cada episódio mostra uma realidade diferente e, geralmente, essas realidades são futurísticas. Por se tratar de um produto de ficção científica, há diversos artefatos de tecnologia avançada nos episódios. Ao assistir a série, o telespectador sente uma espécie de estranhamento, pois a sociedade e a realidade em que ele vive são diferentes - por fatores distintos, dependendo da narrativa - das que são retratadas na série. Tal estranhamento remete ao novum, conceito explicado por Darko Suvin (2010). Segundo o mesmo, em uma obra de ficção científica, o novum é "a coisa nova", aquilo que separa o mundo ficcional do mundo real, causando um distanciamento entre leitor e ficção. Ou seja, o elemento na narrativa que é capaz de despertar um estranhamento cognitivo em quem lê ou assiste a obra, mas que é tão central e significante para a história que a torna completamente lógica (SUVIN, 2010, p.89). Um exemplo clássico de novum seria a máquina do tempo, que possibilita os personagens a viajarem para outras épocas ou visitar o passado/futuro.

Nem sempre o novum é representado como algo tecnológico; em alguns casos, ele pode ser a própria realidade ilustrada no mundo ficcional, mas esse, geralmente, não é o caso dos episódios de Black Mirror. Em "USS Callister", por exemplo, o novum seria a possibilidade de multiplicação do DNA humano, com o propósito 
de criar cópias de determinados indivíduos e usá-las para certas finalidades. A possibilidade de duplicação de DNA aponta para a ideia defendida na introdução de The Gothic Body, em que Hurley explica o conceito de abhuman. Hurley observa que construções de identidade tradicionais estavam dando lugar a criação de outras novas formas a partir da virada do século; essas novas formas são nomeadas de abhumans (1996, p.3). Além disso, "o indivíduo abhuman é aquele não-tão-humano, caracterizado por sua variabilidade mórfica, correndo o risco de se tornar o outro" (1996, p.4, tradução livre) $)^{2}$. A própria definição de Hurley converge com o conceito do duplo, ainda que, nesse caso, tornar-se o outro seja possível através da variabilidade na construção de identidade do indivíduo. Em "USS Callister", há uma nova forma de construir a identidade do sujeito, através da duplicação de seu DNA. Enquanto na literatura, o duplo aparecia, de forma frequente, como um elemento sobrenatural; em produtos de ficção científica, ele é criado a partir de procedimentos tecnológicos ou científicos. Isto quer dizer que, na maioria dos casos, a construção do duplo na ficção científica é justificada por esses procedimentos ${ }^{3}$.

Considerando ainda a criação de novas formas de identidade, é importante refletir sobre o propósito de Daly em criar cópias de seu DNA e de seus colegas de trabalho. O programador é um dos sócios da Callister Inc., juntamente com James Walton; o primeiro é o responsável pela criação dos produtos vendidos pela empresa e este último fica a cargo de administrá-la, sendo o CEO da

2 No original: "The abhuman subject is a not-quite-human subject, characterized by its morphic variability, continually in danger of becoming not-itself, becoming other."

30 duplo também pode ser um resultado equivocado de alguma experiência, mas, ainda assim, é necessário que haja um procedimento para que ele seja criado. 
companhia. Seu relacionamento com Walton é conflitante. O sócio parece tratar Daly bem, mas o último tem ressentimentos por se sentir explorado e enganado por Walton. Nada é muito explícito no episódio e o conflito entre os dois é velado, de certa forma. No entanto, o telespectador entende um pouco como Daly se sente quando Walton, no jogo de realidade simulada e com o objetivo de criar uma armadilha para o sócio, confessa e pede desculpas por seus erros para com o programador. Além disso, por Daly ser solitário e introspectivo, sua interação com os demais colegas de trabalho também não é prazerosa, enquanto Walton é querido e bem-quisto pela maioria dos funcionários - o que desperta o ciúme e a inveja de Daly. No que diz respeito a sua vida, Robert Daly vive em sua casa sozinho. Passa a maior parte de seu tempo livre jogando e não parece ter vínculo afetivo com as pessoas. Não tem interesses românticos, tampouco vida social; e sua autoestima também não é elevada, pois sabe que os outros lhe enxergam com um certo desdém.

É nesse contexto em que Daly dedica boa parte de seu tempo no jogo de realidade simulada que ele mesmo criou. A finalidade do programador, ao criar cópias do DNA de seus colegas de trabalho, é poder conviver com eles em uma outra realidade ainda que ela não seja real, e apenas simulada tecnologicamente. No entanto, é importante mencionar que ele não tem a intenção de convivência no sentido de conhecê-los melhor e interagir positivamente com os mesmos. Daly é o comandante de uma nave espacial e os funcionários da Callister Inc. - inclusive seu sócio - fazem parte da sua tripulação. Na espaçonave, ele se sente absolutamente no controle e poder sobre todos, já que 
aquela realidade e as cópias foram especialmente criadas por ele. Por essa razão, Daly se sente no direito de comandar e torturar os duplos de seus colegas de trabalho - pontos que serão desenvolvidos mais à frente neste artigo.

Se o alter-ego geralmente retrata uma personalidade diferente do Ego, é curioso pensar como o alter-ego de Robert Daly é autoritário e controlador, enquanto ele próprio é um sujeito submisso e passivo. Uma curiosidade importante acerca do episódio é que logo em sua primeira cena, em sua nave espacial, Capitão Daly, é bem-sucedido em uma missão contra seu maior inimigo no jogo, Valdack. Já no próximo cenário, o elevador da Callister Inc., Daly está em silêncio, de cabeça baixa e aparência apática, ao redor de outros funcionários; transmitindo ao telespectador a ideia de que a presença de Daly na empresa é indiferente, já que sua apatia e falta de interação social o deixam quase imperceptível, de certa forma. No jogo de realidade simulada, o comandante é sagaz, capaz de tomar decisões rapidamente e correr riscos. Por sua vez, na realidade, por passar tanto tempo de sua vida obedecendo ordens ou vendo Walton tomar conta de uma empresa gigantesca, o que Daly realmente queria era estar em comando. Contudo, ele confunde a ideia de comandar com ser abusivo para com o outro. O jogo, então, é a oportunidade que ele tem de ser quem ele realmente deseja ser na vida real, mas não consegue; então, acaba optando pela opressão como forma de vingança na simulação. 


\section{OBJETIFICAÇÃO DO OUTRO E INSTRUMENTO DE PUNIÇÃO}

Há dois pontos importantes a serem discutidos no que diz respeito à forma como o Homem enxerga a figura do duplo em "USS Callister": a objetificação e a utilização do outro como instrumento de punição. O primeiro, a ser defendido neste parágrafo, está relacionado ao fato de que, à medida em que a reprodução de uma cópia é possível através de recursos tecnológicos, sua criação passa a ser controlada pelo humano; ou seja, o Homem é o detentor do poder da criação, neste caso - ele tem a decisão de criar a cópia ou não. No entanto, a partir do momento em que o Homem decide criar a cópia de um indivíduo como meio para beneficiar a si próprio através daquela duplicação, é possível caracterizar essa reprodução como um objeto de consumo - algo que o humano tem o desejo e o interesse em adquirir, para vantagem exclusivamente pessoal.

Na literatura gótica, o duplo poderia ser encarado, em algumas vezes, como um fantasma - até pelo fato de que, em muitos casos, a duplicação surgia por razões sobrenaturais. Segundo Wolfreys (2002), o espectro assombra a modernidade e está no coração das narrativas modernas ${ }^{4}$ (p.3, tradução livre). É possível afirmar que o duplo é o próprio espectro em "USS Callister", pois, ainda de acordo com o autor (2002, p.3), o retorno de fantasmas resulta em uma assombração dentro da trama. É válido dizer que, quando se fala em fantasma, não se quer dizer apenas de elementos sobrenaturais, já que esse retorno fantasmagórico pode ser fruto de uma repetição (WOLFREYS, 2002, p.3). Isto é, o processo de duplicação é resultado de uma reprodução do eu original, afinal uma cópia sua está sendo

4 No original: "A spectre haunts modernity, and the spectral is at the heart of any narrative of the modern." 
criada. Essa cópia, mesmo que não se trata de um ser sobrenatural, é capaz de assombrar em "USS Callister", se considerarmos o lado perverso de Daly, representado em seu alter-ego, por exemplo.

Considerando o fato de que Daly reproduz uma cópia de si mesmo, é possível afirmar que ele o faz para dar a vida a seu alterego, primeiramente, e também para ter a liberdade de realizar suas fantasias e desejos reprimidos. Freud em "O Ego e o Id" (1976) observa que o Id é a parte da psique humana que contém os instintos básicos e primitivos; este seria o inconsciente do indivíduo. O Ego, por sua vez, é a parte da personalidade responsável por equilibrar os impulsos do Id e a realidade; ou seja, o Ego reprime os instintos do Id, para que o indivíduo seja sociável e civilizado dentro da sociedade. No jogo de realidade simulada de "USS Callister", as vontades e desejos reprimidos pelo Ego de Daly são expostos e praticados por seu alter-ego sem nenhuma preocupação moral. Nesse caso, o duplo é um objeto de consumo para que Daly tenha a possibilidade de realizar coisas que seu próprio Ego e a sociedade consideram imorais.

Quanto ao outro, é importante analisar a forma como Daly objetifica a cópia para seu próprio prazer. Um exemplo dessa objetificação é o fato de que as mulheres no jogo de realidade simulada usam vestimentas curtas e muito justas, a fim de mostrar a forma de seus corpos. Essa é uma representação sexista do corpo da mulher, em que o mesmo deve sempre evidenciar a sua forma escultural, estimulando os olhos e o prazer do homem. Ou seja, a mulher é retratada como aquela figura submissa e reverente - além de ser também um símbolo sexual -, com a função de agradar e satisfazer os homens, a começar pela 
maneira que se produzem e se vestem. Dessa forma, Daly não só tem controle sobre o outro - escolhendo até sua representação estética, como também é capaz de obter o domínio sobre seus próprios desejos sexuais, afinal o Capitão é livre de julgamentos para sexualizar o corpo feminino no jogo e usar as mulheres como meio de satisfazer suas próprias fantasias.

O segundo ponto a ser analisado sobre a forma como o Homem entende a criação de uma cópia seria usá-la a fim de castigar o outro. Além de objetificar o corpo feminino, Daly também utiliza os duplos digitais de seus colegas de trabalho para aprisioná-los, como forma de punição por ressentimentos do eu. É importante ter em mente que, a partir do momento em que o programador reproduz o DNA humano, os duplos têm consciência de que são cópias; ou seja, eles sabem que estão presos em um jogo de realidade simulada, embora os originais não tenham o conhecimento de que seu DNA foi copiado. Daly consegue clonar o DNA de seus colegas de trabalho de uma maneira arbitrária; através de um copo usado, um fio de cabelo, entre outros. As cópias mantêm os mesmos sentimentos que têm pelo Daly original, porém, no jogo, os sentimentos são ainda mais agravantes, uma vez que eles sabem do que o Capitão, representantes dos instintos e desejos de Daly, é capaz de fazer. Entretanto, as cópias não podem expressar aversão, raiva ou qualquer sentimento negativo, uma vez que Daly é quem domina a nave e deixa bem claro que eles estão submissos e subordinados a ele. Pelo contrário, os tripulantes precisam demonstrar apreço e admiração por seu comandante.

Aprisionados na nave do Capitão Daly, sob seu controle e poder, os duplos podem ainda ser castigados como consequência 
de eventualidades que acontecem entre ele e seus companheiros de trabalho não só dentro, mas também fora do jogo. Observase, na narrativa de "USS Callister", o prazer em punir o outro. A verdadeira intenção de Daly era penalizar os originais; no entanto, quando não é possível castigar o humano - reprimindo os instintos animalescos do Id (FREUD, 1976) -, castiga-se a sua cópia em Black Mirror. Isto parece isentar o torturador, de certa forma, uma vez que ele está objetificando e torturando uma cópia para se vingar, sem machucar fisicamente o original. Por exemplo, em um determinado momento no episódio, há uma cena em que Walton narra o momento em que Daly usou o DNA de Tommy, seu filho, para torturá-lo psicologicamente dentro do jogo, fazendo com que o pai assistisse à criança se desintegrando no espaço. Assim como Daly usa o jogo como uma oportunidade para realizar suas fantasias e desejos sexuais, a realidade simulada também serve como um escape para extravasar a raiva que ele guarda de seus companheiros.

De acordo com Immanuel Kant em Groundwork of the Metaphysics of Morals, nenhum ser racional deve ser usado como meio para beneficiar a si próprio, pois a sua existência tem um valor (1997, p.38). Ou seja, independentemente de ser humano ou não, usar um ser capaz de agir racionalmente para vantagem própria fere a dignidade do mesmo (1997, p.42). Se as cópias dos colegas de Daly têm a consciência de que são duplos e são capazes de raciocínio, ele rompe com o respeito e a dignidade a elas, à medida em que as castiga e as mantém aprisionadas. 


\section{CRIADOR X CRIATURAS}

Considerando a forma da literatura gótica, há muitos elementos convencionais que fazem parte de suas obras, mas três se destacam por sua frequência e relevância para sua estrutura narrativa: "o locus horribilis ${ }^{5}$, a personagem monstruosa e a presença fantasmagórica do passado" (FRANÇA, 2016, p.2493). Apesar de "USS Callister" ser um episódio de ficção científica, existem algumas nuances do Gótico em sua trama e os dois primeiros elementos citados por França são importantes para este artigo.

Antes de entrar em detalhes a respeito dos elementos formais do Gótico, é importante ressaltar que uma das semelhanças com obras desse gênero seria a própria relação entre criador e criatura, como em um dos grandes clássicos da literatura gótica, Frankenstein (1818), de Mary Shelley, embora essa relação seja representada de maneira um pouco diferente no episódio em questão. Em relação ao criador e sua criatura, assim como Wolfreys (2002) aponta, a reprodução do eu causa horror, afinal algo que tinha sido oculto no eu retorna no outro. Utilizando o conceito de unheimlich $^{6}$ de Freud (2010), Wolfreys declara que, pelo fato de o inquietante não vir de um lugar desconhecido, novo e sim de algo que é íntimo, mas que fora reprimido, o que perturba o indivíduo é o retorno daquilo que foi colocado de lado, como uma espécie de segredo. É por isso que o telespectador se choca ao assistir ao alter-ego de Daly 5 Espaços narrativos sombrios, misteriosos e opressivos.

6 "'O inquietante': das Unheimliche. Por razões que ficarão evidentes no próprio texto, é desnecessário chamar a atenção do leitor para a insuficiência da tradução desse termo, que é também o título do ensaio. Limitemo-nos a registrar as soluções adotadas em algumas versões estrangeiras deste ensaio (duas em espanhol, a da Biblioteca Nueva e a da Amorrortu, a italiana da Boringhieri, a francesa da Gallimard e a Standard inglesa): Lo siniestro, Lo ominoso, II perturbante, L'inquiétante étrangeté, The uncanny." (SOUZA, Paulo César, 2010). 
cometer todas as atrocidades com as cópias de seus companheiros de trabalho, pois a duplicação consiste na reprodução do eu original, mas sem repressões. Quando assistimos a "USS Callister", a monstruosidade ocasionada pelo Capitão dentro do jogo é apenas um reflexo daquilo que o eu original gostaria de fazer, mas é vetado.

Voltando aos três elementos destacados por França (2016) e, no que diz respeito a "USS Callister", é possível afirmar que a espaçonave é o próprio locus horribilis. Afinal, é nela que o Capitão Daly tem liberdade, controle e poder para oprimir seus subordinados. Na verdade, o próprio jogo já entrega esse poder a Robert, porém a maior parte dos acontecimentos do jogo acontece na nave, por isso ela pode ser considerada um espaço opressivo e misterioso, uma vez que o Capitão é o único capaz de saber quais eventos acontecerão em seguida, deixando seus tripulantes inteiramente sob suas ordens. No que diz respeito à caracterização da nave, suas cores não são tão sombrias, entretanto, o lado oculto do Daly original, o qual é mantido às sombras, é totalmente revelado nesse espaço; então, ela acaba se tornando sombria, de certa forma, por trazer à tona aspectos que estavam ocultos.

O outro elemento característico do Gótico presente no episódio é a presença monstruosa. O Capitão Daly é a figura opressora, autoritária e capaz de instrumentalizar o outro para que este sirva a seu favor. Além de todas essas características sombrias, ele ainda sexualiza suas companheiras de trabalho, usando-as para realizar suas fantasias e poder sentir-se como um grande conquistador - já que as mulheres da tripulação se permitem ser objetificadas até um determinado momento, por medo de sofrerem retaliação. Em uma releitura contemporânea de obras de literatura gótica, Capitão Daly 
é o monstro que oprime e mantém seus subordinados aprisionados em um jogo de realidade simulada, sob ameaça caso eles tenham a intenção de fugir; como foi o caso de Tommy, filho de Walton, que teve seu DNA copiado para torturá-lo no jogo.

Na literatura, o duplo é considerado um ser que desperta uma sensação inquietante, pois ele é a dissociação do eu original, a parte renegada pelo eu que foi esquecida (FREUD, 2010). Ainda na literatura, a duplicação pode ser a representação da consciência moral do indivíduo ou a manifestação dos instintos do Id, por exemplo; e, por isso, ela é familiar, já que faz parte da identidade do sujeito, mas estranha, ao mesmo tempo, por ter sido reprimida. Se pensarmos em fatores que causam um efeito inquietante em "USS Callister", observa-se que o duplo continua sendo representado como um ser unheimlich, pois, mesmo sendo uma parte copiada do eu original (familiar), ele também é novo (misterioso), podendo assombrar sua parte original por tratar-se de uma reprodução, assim como Wolfreys (2002) afirmou ser possível. Além de sua característica inquietante, a cópia também demonstra ser capaz de rebelar-se contra seu criador - como será visto mais à frente. Otto Rank também observa que o duplo pode surgir para anunciar a destruição do eu (1971, p.83-86) e, portanto, acaba sendo interpretado como uma assombração fantasmagórica.

Em contrapartida, o eu original se torna um ser inquietante por ser capaz de objetificar e sacrificar o outro, provocando o horror que Wolfreys (2002) destacou acontecer através de espectros. Se, de acordo com Wolfreys, a reprodução de algo ou alguém resulta em uma assombração fantasmagórica (2002, p.14), esse ser 
reproduzido é igualmente atormentado pelo humano7. Ainda que se trate de um sujeito familiar para a cópia - afinal, os duplos têm a consciência de que são reproduções e reconhecem a figura do Robert Daly original no Capitão -, ele revela a monstruosidade que estava oculta dentro do Homem, mostrando-se disposto a sacrificar o outro, a fim de obter o controle sobre os outros e seu Ego, suprimindo sua humanidade, de certa forma. Ao instrumentalizar um outro ser racional, o humano não demonstra nenhum tipo de empatia ou compaixão para com a cópia. Pelo contrário, o duplo é usado como um meio para satisfação pessoal e isso basta para o eu.

Em contraponto a obras literárias, o duplo não é mais o ser que persegue e atormenta o eu original (RANK, 1971); em Black Mirror, ele assume a função de vítima, por ser oprimido e aprisionado pelo Homem. Durante boa parte do episódio, o telespectador vê as cópias dos colegas de trabalho de Robert sendo completamente submissas ao Capitão, pois sabiam que enfrentariam consequências, caso tentassem fugir. É importante observar que essas cópias reproduzidas só são submissas a Daly porque ele é o seu criador. A questão da moral e o ferimento à dignidade do outro, observados por Kant (1997), não são um problema exclusivo de Robert Daly, mas sim da humanidade em geral. Qualquer outro indivíduo que fosse reprimido por muito tempo e tivesse a oportunidade de aprisionar aqueles que the causam algum ressentimento poderia ser tão autoritário e opressor quanto Daly foi para com os seus duplos. O Homem é representado pelo programador, neste caso, para revelar o que o

7 Vale ressaltar que a forma de assombrar não é a mesma, mas a intensidade em que eu original e cópia são assombrados é semelhante. Arrisco dizer, ainda, que, no caso de Black Mirror, a cópia seja mais atormentada do que o próprio eu. 
humano é capaz de realizar contra o outro, quando se entrega ao seu lado passional.

Entretanto, por se tratar de uma reprodução do eu original, o duplo parece ter a mesma capacidade de ressentimento e vingança que o humano possui. No final do episódio, Robert Daly acaba sendo derrotado por seus tripulantes - tanto no jogo, quanto na vida real. Isto quer dizer que as próprias criaturas foram capazes de vencer seu criador. O duplo consegue superar a posição de vítima e se vinga da perversidade humana de quem o reproduziu. Todavia, é válido apontar para o fato de que as criaturas fazem com seu opressor algo parecido com o que o último fazia com elas, quando oprimidas. As cópias realizam uma armadilha para se libertar de Daly, porém o deixam aprisionado tanto no jogo, quanto na realidade também. Essa inversão de quem tem o poder mostra que o duplo deixa de assumir a posição de submissão para oprimir por vingança, nesse caso. É importante salientar que o aprisionamento de Daly é necessário para que os demais possam ser livres no jogo. No entanto, existe um prazer em ver o antigo Capitão aprisionado e expulso daquela realidade para sempre.

Linda Dryden, em The modern Gothic and literary doubles (2003), afirma:

É raro encontrar um conto sobre duplos ou duplicação que não contenha fortes elementos do horror gótico e uma morte inevitável. O duplo é a ameaça à integridade da identidade e frequentemente uma evidência de uma força gótica e supernatural que traz consigo morte e destruiç̧ão. (p.38, tradução livre) ${ }^{8}$

8 No original: "It is rare to find a tale of doubles or doubling that does not contain strong elements of Gothic horror and inevitable death. The double is a threat to the integrity of the self, and frequently evidence of a Gothic, supernatural force at large that brings with it death and destruction" 
A derrota de Daly não é um exemplo de morte física, como Dryden destacou, mas pode-se defender a ideia de que a sua humanidade foi destruída. Seu lado humano foi reprimido, uma vez que Daly não demonstrava sinais de compaixão, mas apenas frieza ao instrumentalizar não só o outro, mas ele mesmo também - ambos para satisfação pessoal.

O Gótico fin-de-siécle consistentemente permeia a fronteira entre fenômenos naturais e sobrenaturais, hesitando entre aspectos científicos e ocultos de eventos inexplicáveis. O domínio que o gênero explora é uma área cinza na fronteira entre o familiar e o desconhecido, ou fenômenos extra-racionais, com o sobrenatural definido como oculto por si, mas como o produto de forças naturais misteriosas que o cientista ainda não foi capaz de explicar. (HURLEY, 1996, p.16-17, tradução livre) $)^{9}$

Hurley, ao fazer esta observação, estava analisando o Gótico em narrativas de ficção científica em que o horror pode ocorrer quando algo não consegue ser explicado cientificamente, extrapolando os limites do conhecimento humano, permanecendo, assim, oculto em sua natureza. No que diz respeito ao desenvolvimento de "USS Callister", é justificado, de acordo com a ciência, a forma como Robert consegue duplicar o seu próprio DNA e o de seus colegas, criando duplos digitais para que todos pudessem ser componentes do jogo criado por

9 No original: "The fin-de-siecle Gothic consistently blurs the boundary between natural and supernatural phenomena, hesitating between scientific and occultist accountings of inexplicable events. The realm the genre explores is the grey area at the borderline between known and unknown, or extra-rational phenomena, with the supernatural defined not as the occult per se, but as the product of mysterious natural forces the scientist has not yet been able to explain". 
ele; até porque o novum precisa fazer com que a narrativa seja lógica para que seu leitor/telespectador acredite nela, como já foi citado anteriormente neste artigo (SUVIN, 2010).

No entanto, o que não é explicado acerca da criação de cópias virtuais de seres humanos é o que elas revelariam, no que diz respeito ao Homem e a elas próprias. A força natural misteriosa que ultrapassa o entendimento humano, explicada por Hurley, em "USS Callister" seria a monstruosidade que é reprimida dentro do indivíduo por muito tempo e passa a ser revelada, à medida em que ele tem o poder e o controle sobre um outro ser em suas mãos. Em relação às cópias, por sua vez, essas também são capazes de se rebelar contra seu criador, desde que sejam oprimidas e exploradas pelo mesmo. A exploração dos limites também se aplica às criaturas pois, uma vez que elas são aprisionadas e percebem que a única forma de se libertar é indo contra seu opressor, elas se unem com o único propósito de derrotar quem as criou e as enclausurou como meio de objetificação, para vingar-se e adquirir liberdade.

\section{CONSIDERAÇÕES FINAIS}

Considerando as ideias abordadas anteriormente, pode-se afirmar que a criação de uma cópia permite que o Homem seja o detentor do controle sobre o outro - ainda que este outro se trate de uma cópia, e não de um humano, propriamente dito. A partir do momento em que Daly cria as cópias digitais de seus colegas de trabalho, ele se torna o Criador de todos estes duplos. Além disso, Daly revela um lado sombrio através de seu alter-ego, o Capitão Daly, por assumir uma postura autoritária e ser capaz de castigar e 
punir suas criaturas, pelo mau relacionamento que o original tem com seus funcionários, na vida real.

Quando Daly decide reproduzir a cópia de seus colegas de trabalho para que elas participem do jogo de realidade simulada que ele criou, a fim de depreciá-los por qualquer desentendimento - direto ou não - que tenha existido no mundo original, isto quer dizer que a intenção do programador era de criar "bonecos" para que ele pudesse torturar e se divertir durante o processo. Ou seja, o duplo se torna um objeto de consumo para Daly, uma vez que ele o deseja apenas para benefício próprio, sendo capaz de adquiri-lo - no caso de "USS Callister", a aquisição do duplo como objeto de consumo acontece através do uso de DNA para criação de cópias virtuais.

Além de objetificar a cópia, Daly também a utiliza como instrumento de punição para com o outro. Pelo fato de o original ter personalidade introspectiva e guardar rancor por se sentir excluído e malquisto por seus colegas de trabalho, o programador usa os duplos para castigá-los. Ou seja, já que ele não pode punir seus desafetos originalmente, seu alter-ego é opressivo e abusa das formas de tortura de suas cópias, o que aponta para a questão da moral observada por Kant (1997), já que o autor considera uma prática imoral a instrumentalização de um ser racional, ferindo a sua dignidade.

Por fim, apesar de "USS Callister" ser um episódio de um seriado de ficção científica, é possível perceber elementos góticos dentro desta narrativa, como a figura monstruosa, representada pelo alter-ego de Daly. O monstro contemporâneo caracterizado 
através da duplicação de Daly é capaz de assombrar, oprimir e até surpreender, não só suas criaturas, mas também o telespectador da série. O alter-ego pode ser considerado surpreendente, pois o Daly original é passivo, submisso e solitário, mas seu duplo causa um certo impacto por retratar Daly de uma forma tão diferente. Assim como discorrido anteriormente, a nave também é um elemento gótico dentro da trama, pois é o lugar que aprisiona as cópias digitais de Daly e é onde o Capitão realiza a maioria de suas torturas e castigos. Mesmo tratando-se de um produto de ficção científica e, consequentemente, contemporâneo, pode-se afirmar que "USS Callister" é uma narrativa em que o aprisionamento e a figura do monstro são algumas de suas características mais marcantes, assim como obras clássicas da literatura gótica.

\section{REFERÊNCIAS}

BLACK MIRROR (2017). "USS Callister". 4a temporada, episódio 1. Toby Haynes (Dir.). Charlie Brooker e William Bridges (Rot.). Reino Unido.

CARDOSO, André Cabral de Almeida (2018). "Precarious humanity: the double in dystopian science fiction". Gragoatá, 23-47, 888-909.

DRYDEN, Linda (2003). The Modern Gothic and Literary Doubles: Stevenson, Wilde and Wells. Basingstoke (UK); Nova York: Palgrave MacMillan.

EAGLETON, Terry (1976). Marxism and Literary Criticism. Berkeley e Los Angeles: University of California Press.

FRANÇA, Júlio (2016). "O gótico e a presença fantasmagórica do passado". Anais eletrônicos do XV encontro ABRALIC. Rio de Janeiro: Dialogarts. v.1, p.2492-2502. FREUD, Sigmund (1976). "O Ego e o Id". In: O Ego e o Id, Uma Neurose Demoníaca do Século XII e Outros Trabalhos, vol. 19 (1923-1925). Rio de Janeiro: Imago, p.32-41 (2010). "O inquietante". In: Obras completas, vol. 14: História de uma neurose infantil ("O homem dos lobos"), Além do princípio do prazer e outros textos (1917-1920). São Paulo: Companhia das Letras, p.328-376. 
HURLEY, Kelly (1996). The Gothic Body: Sexuality, materialism, and degeneration at the fin de siècle. Cambridge (UK): Cambridge UP.

KANT, Immanuel (1997). Groundwork of the Metaphysics of Morals. Cambridge (UK): Cambridge UP.

RANK, Otto (1971). The Double: A Psychoanalytic Study. Chapel Hill (NC): The U. of North Carolina P.

SUVIN, Darko (2010). Science Fiction and the Novum. In: . Defined by a Hollow: Essays on Utopia, Science Fiction and Political Epistemology. Oxford; Bern: Peter Lang, p.67-92.

WOLFREYS, Julian (2002). Victorian Hauntings: Spectrality, Gothic, the Uncanny and Literature. Basingstoke (UK): Palgrave. 